\title{
A Review of Strategic Process Research
}

\author{
Anne S. Huff \\ Rhonda Kay Reger \\ University of Illinois
}

\begin{abstract}
This article reviews research on the process of strategic management reported over the last six years in seven leading journals. Nine "streams" of work are identified and critiqued. The field is described as giving continuing attention to the possibilities and problems of strategic planning and decision making, but also moving into new areas of research-especially the problem of how the attention of decision makers is directed toward specific agendas for action. We recommend more studies that simultaneously consider strategy formulation and implementation and more studies that attempt to integrate methods and concerns across the various areas of process research. Finally, we recommend that future research give simultaneous attention to the content as well as the process of strategy.
\end{abstract}

The discipline of strategic management traces its origin to such landmark works as Chandler's Strategy and Structure (1962), Ansoff's Corporate Strategy (1965), and Andrews' The Concept of Strategic Management (1971). These three books were among the first to propose formally the distinction between the process of strategic management and the content of strategy. The distinction has tended to divide research ever since: researchers study content, or they study process. The publication of Strategic Management, edited by Schendel and Hofer (1979), further solidified these categories by suggesting that this and other subdivisions would facilitate research progress in the field.

Last year, Fahey and Christensen (1986) reviewed current trends in strategic content research in this journal. This review looks at current directions in strategic process research. However, we will argue that the distinction between process and content, which seems so reasonable on the face of things, is now becoming an impediment to progress in strategic management research.

\section{Process versus Content}

Strategy research characterized as content research has been focused on the subject of the strategic decision itself. In the last decade, considerable attention has been devoted to learning more about merger, acquisition, and divestment

Address all correspondence to Anne S. Huff, Department of Business Administration, 350 Commerce West, University of Illinois, Champaign, IL 61820.

Copyright 1987 by the Southern Management Association 0149-2063/87/\$2.00. 
strategies; entry, exit, and mobility barriers; product/market differentiation; turnaround; vertical integration and similar subjects. Content research has focused on linking specific decisions and broader economic structures to performance outcomes. It has also given considerable attention to defining similarities and differences among strategic units within the firm, among strategic groups within industries, and among firms in similar circumstances, such as growth or decline in demand.

Process research, in contrast, has been defined as research primarily focused on the actions that lead to and support strategy. Research in this area has included prescriptive and descriptive work on planning methods and decision making, with attention directed toward the effectiveness of alternative means for generating and implementing strategy. The impacts of individual and group characteristics and organization structure on the formation and implementation of strategic decisions have also concerned researchers in this area.

The task of reviewing process research is made difficult by the large amount of work in other fields that might be drawn upon to understand strategic processes. Work in organization behavior and organization theory, as well as research in more distant fields such as public administration, sociology, political science, international relations, and education, might be included in a comprehensive review of relevant work. In the limited space available here, we decided to concentrate on work by individuals who identify themselves with the field of strategy, ignoring work in other social science fields, as well as closely related but more widely reviewed work on problem solving and decision making.

As befitting a young but rapidly growing field, the review focuses on recent work (published after 1980) with the intent of summarizing the current state of the field for researchers. The bibliography upon which the review is based was generated by reviewing work published in seven journals (Strategic Management Journal, Journal of Business Strategy ${ }^{\prime}$, Academy of Management Journal, Academy of Management Review, Administrative Science Quarterly, Journal of Management, and Management Science). This search, conducted at the beginning of the study and again after the categories developed below were well established, resulted in a bibliography of 193 items representing the current state of the field. The bibliography was far larger than we anticipated, but precisely for this reason we decided it would be worthwhile to outline the entire body of work rather than focus on a subset of articles.

\section{Major Divisions in Strategic Process Research}

To help make sense of the bibliography we first broadly divided it according to the step in the strategic process covered, using Andrew's (1971) enduring division between those who have focused on the process of strategy formulation (how decisions are generated) versus those who focus on the process of strategy implementation (how decisions are put into action).

The second division that seemed useful concerned research purpose. Research

\footnotetext{
J JBS is unique in this set of journals for including a large number of articles by consultants and practitioners. Given the size constraints of this review, and our intent to review the field for a research audience, we reluctantly did not include these articles.
} 
was classified as taking either a normative approach (how things should be done) or a descriptive approach (how things are done). This dichotomy reflects the desire to do work of immediate utility for those with decisions to make versus the appeal of classic standards of science. Subsumed under both categories are theoretic articles. We considered making this a third dimension, but found the above dichotomy a more useful way to subdivide current work. Interestingly, descriptive research has tended to span several strategic management steps and has reported an intermingling of steps, whereas normative works have been more likely to separate the steps in the strategic processes they cover. Also interesting is the fact that normative work has predated descriptive empirical work on many topics.

Finally, the rationality assumptions researchers have held provided a third dimension along which strategic process research done in the last several years could be arrayed. Some researchers have suggested strategic management processes are, or should be, sequentially rational, analytical processes. Others have suggested that decision-makers are limited information processors and organizations are political entities with individual and group interest determining activity. In this view, the strategic management process has, and must have, a rationality reflecting individual, organization and political characteristics that is more idiosyncratic and less easy to prespecify.

Dividing each of these three dimensions into two polar approaches yielded eight distinct alternatives for strategic management process research, as illustrated in Figure 1. In addition, a ninth, integrative, alternative identifies work that has encompassed many of the above distinctions. Research from this perspective has tended to combine description of strategy formulation and strategy implementation (e.g., Quinn, 1980). Some of this work has captured how analysis is carried out in political settings (e.g., Bower, 1970). Finally, although primarily descriptive, research in this area often has included discussion of the normative implications of descriptive accounts of decision making.

Although categorization was not always easy (usually because an article had

Figure I

Dimensions of Strategic Process Research

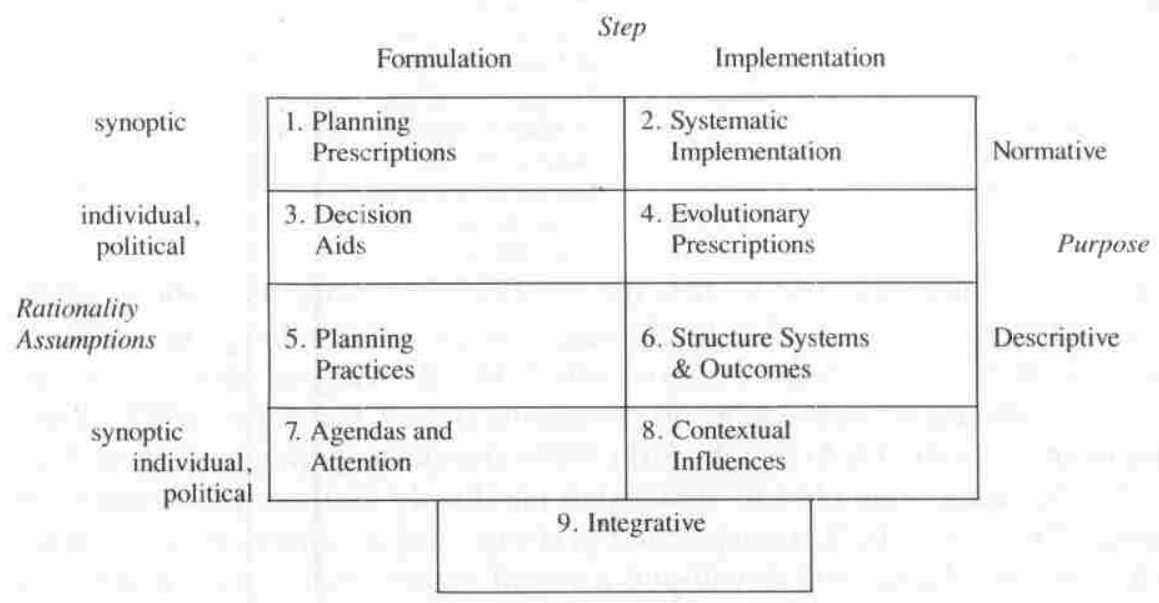


characteristics that fit more than one cell), we found the nine-cell schema helpful in trying to understand the increasingly diverse directions of process research. Once the articles were classified, we sought to delineate the major research issues in each area and identify where possible major precursors to current work. The following pages provide that information, along with a brief critique of each approach to understanding strategy process. In summary, we chose a few exemplary articles-articles that we believe represent particularly promising process research-and identified six characteristics that deserve emulation in future research.

\section{Nine Major Streams of Strategic Process Research}

The upper left cell of Figure 1 encompasses those studies that have given normative prescriptions for how strategies should be formulated. Articles in this stream, titled Planning Prescriptions, are of particular interest since they followed the path laid down by almost all process oriented strategy work done before the last few years. Early work on planning, typified by the work of Steiner (1969, 1979) and Ackoff (1970), was directed toward helping organizations rationalize planning and strategic decision-making systems and relied primarily on logic and consulting experience to support advice on how strategy should be formulated. Systematic rationality and logic, illustrated with case experience, continue to justify current work in the area.

Recent work can be subdivided into four groups:

General Models of Planning

Ackoff, $S M J, 81$

Ansoff, JBS, 86

Camillus, SMJ, 82

Chakravarthy, AMR, 84

Gharajedaghi \& Ackoff, SMJ. 84

Leontiades, SMJ, 83

McGinnis \& Ackelsberg, JBS, 83

Miesing \& Wolfe, MS, 85

Mitroff \& Mason, AMR, 82

Specific Steps in the Planning Process
Ansoff, SMJ, 80
Charan, JBS, 82
Day, JBS, 83,86
Diffenbach, SMJ, 82
Hosmer, JBS, 82
Hunsicker, SMJ, 80
King, JBS, 81
Klein \& Newman, JBS, 80

\author{
Specific Environments \\ Bryson, SMJ, 81 \\ Hatten, SMJ, 82 \\ Mahon \& Murray, SMJ, 81 \\ Mitchell \& Mitchell, AMR, 80 \\ Montanari \& Bracker, SMJ, 86 \\ Nutt, SMJ, 84a \\ Specialized Approaches \\ Blyth, Briskey \& Rappaport, JBS, 86 \\ Desta, JBS, 85 \\ Dutta \& King, SMJ, 80 \\ Edmunds, JBS, 82 \\ Fombrun \& Astley, JBS, 83 \\ Hofer \& Haller, JBS, 80 \\ Hoffman, JBS, 85 \\ McInnes \& Carleton, $M S, 82$ \\ Melcher \& Melcher, AMR, 80 \\ Mokwa, JBS, 86 \\ Mueller \& Smith, JBS, 84 \\ Naylor \& Tapon, MS, 84 \\ Woo, MS, 84
}

One set of work has continued to view the practice of planning as a whole, offering overarching prescriptions for developing strategy. Within this group, Mitroff \& Mason (1982) were perhaps the most ambitious, drawing on epistemology to delineate 12 alternative approaches to generating policy. Camillus (1982), Gharajedaghi and Ackoff (1984) and Ansoff (1986) also developed general models of planning, but each attempted to synthesize previously dichotomous aspects of planning. The first article incorporated participation of stakeholders with research analysis, the second developed a social system model intended to su- 
percede the dichotomy between mechanistic and organismic views of organizations, and the third integrated incremental and analytical dimensions of planning.

Broad perspectives on planning and policy making were offered for public/notfor-profit organizations by Mitchell and Mitchell (1980), Bryson (1981), Hatten (1982), Nutt (1984a) and Montanari and Bracker (1986). The prescriptions offered by these authors, in our view, are also of potential utility for those interested in for-profit organizations. For example, Bryson's discussion of the opportunities raised by crisis, or Montanari and Bracker's observation that interest in planning varies in response to the tenure of the policy maker, might be incorporated in models being developed for business.

The remaining article in this set, by Mahon and Murray (1981), looked at strategic and structural differences affecting planning in regulated industries. We were surprised that few articles discussing specific environments appeared in the planning prescriptions area. However, the categories that follow do include other articles that have recognized the importance of environmental context (e.g., Bartlett, 1982; Dickmeyer, 1983; Shrivastava, 1986).

The remaining articles categorized under Planning Prescriptions have either focused on specific steps in the planning process or have advocated a particular perspective for analysis. In the first group, for example, Ansoff (1980), Klein and Newman (1980) and King (1981) offered systematic approaches for spotting and structuring upcoming problems or strategic issues; Hunsicker (1980) and Hosmer (1982) discussed the importance of executive leadership in defining strategic issues; Diffenbach (1982), along with Melcher and Melcher (1980), suggested tools for diagramming or mapping the causal links influencing such issues.

In the last group of articles, suggesting specific approaches to planning, are appeals to use a variety of specific analytical techniques including economic scenarios (Hoffman, 1985), marketing audits (Mokwa, 1986), financial modeling (McInnes \& Carleton, 1982; Naylor \& Tapon, 1982; Woo, 1984), metagame analysis (Dutta \& King, 1980), and futures studies (Edmunds, 1982; Mueller \& Smith, 1984). Four articles that recognized the importance of political issues are also included in this group on the basis of their systematic prescriptions (Blyth, Friskey, \& Rappaport, 1986; Desta, 1985; Fombrun \& Astley, 1983; Hofer \& Haller, 1980).

Many of the articles in the Planning Prescriptions stream are noteworthy for their attempt to retain the broad, integrating perspective traditionally associated with policy making. A sizable number of these articles have drawn upon work in other fields. We anticipate that future work will draw more heavily on industrial economics and will continue to integrate perspectives from more than one field. Chakravarthy's article is one of several that might be chosen as exemplary in its recognition of the economic structures within which firms must plan, and its simultaneous attempt to account for the cognitive limits of decision makers. The planning approach as a whole, however, can still be chastised for advocating an overly heroic approach to strategic management; it has been too optimistic about the possibilities of synoptic, rational analysis. It also has been too far removed from the specific problems of the individual organization trying to find some way 
of achieving sustainable advantages over similar firms. Although Leontiades (1983), for example, showed that firms from quite different industries could be placed in different positions within his framework, the particular problems that planning with his very general categories would solve for any of these organizations remain unclear.

In defense, the conceptual tidiness of systematic rationality may provide a better vocabulary for communication within organizations than more realistic models. The common ground provided by rational models may be particularly important when organizations are faced with unclear problems of strategy (Huff, 1985). Clear prescriptions also delineate the implications of this stream of work for further research in a way that might well be emulated by other management researchers.

The systematic, synoptic approach of the Planning Prescriptions group has been matched by a second, equally straightforward set of work that has focused on prescriptions for Systematic Implementation of strategy once it is formulated. Separate attention to implementation has been a relatively recent phenomenon (Galbraith \& Kazanjian, 1986; Galbraith \& Nathanson, 1978; Hrebiniak \& Joyce, 1984; and Lorange, Morton \& Ghoshal, 1986). Journal articles in the area included the following works:

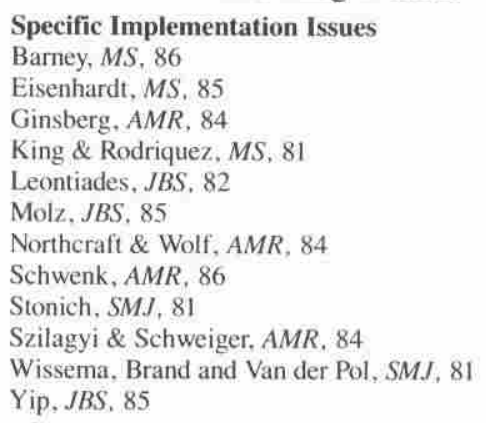

\author{
General Models of Implementation \\ Camillus \& Grant, AMR, 80 \\ Lorange \& Murphy, JBS, 84 \\ Mintzberg, MS, 80 \\ Nutt, AMR, 83 \\ Stengrevics, JBS, 84 \\ Stonich. JBS, 80

\section{Specific Environments} \\ Hax \& Majluf, JBS, 83 \\ Shrivastava, JBS, 86 \\ Snyder, Cox \& Jesse, AMR, 82
}

A number of the dominant themes of implementation have been explored in depth by the largest group of these authors. Subjects covered include the importance of matching managers to strategies (Leontiades, 1982; Szilagyi \& Schweiger, 1984), techniques for assuring participation (King \& Rodriquez, 1981) and increasing commitment (Schwenk, 1986), and the need to match compensation schemes to strategic decisions (Stonich, 1981). Other authors have explored resource allocation decisions (Northcraft \& Wolf, 1984; Stonich, 1980), control (Camillus \& Grant, 1980; Eisenhardt, 1985; Moltz, 1985) and measurement (Ginsberg, 1984).

Although most of these issues have also been covered in organization behavior, strategists have tended to bring a somewhat different perspective to implementation. For example, Northcraft and Wolf (1984), suggested psychologists who investigate commitment have not adequately considered the link between individual decisions and the larger projects of which they are a part. Northcraft and Wolf developed a life cycle model of project costs and expected returns and suggested that for projects with high initial costs, but large revenues anticipated at completion, the "region of rationality" for making further investments despite negative 
results is quite large. In short, decisions that appear biased when studied in isolation may have their own rationality in a larger strategic framework.

We applaud these works for their attempt to bring a strategic perspective to implementation issues, but also feel that they fall prey to complaints about the easy acceptance of sequential rationality. Another potential problem, in theory as well as practice, is the design of implementation lagging behind current thought in strategy formulation. Stonich (1981), for example, suggested means for implementing portfolio-based concepts of strategy, but by the time his work was published many organizations were moving away from portfolio-based planning models. This is not to deny the importance of matching the reward system to corporate intentions (as was Stonich's major concern) but may be taken as an argument for the more integrated views of formulation and implementation that are reviewed below.

Those who have been more concerned by the vagaries of individual psychology, organizational idiosyncracies, and political processes than the preceding two groups of researchers still often have been willing to give advice. On the formulation side is a set of work that focuses on Decision Aids. In contrast to those with more systematically rational expectations, researchers in this area have assumed that strategy formulation is conceptually problematic. Since decision makers fall short of the demands of synoptic rationality, they are expected to benefit from structured decision processes and other aids to help them organize and analyze strategic alternatives.

The precursors to this area include the vast amount of work done in the 1960s and early 70 s on creativity aids and procedures for synthesizing expert opinion. Recent work has included a number of general discussions of strategic decision making as well as work focused on more specific techniques:

\section{General Prescriptions}

Barnes, SMJ, 84

Bartunek, Gordon \& Weathersby, AMR, 83

Bower, JBS, 82

Kunreuther, Linnerooth \& Vaupel, MS, 84

Lenz \& Lyles, JBS, 86

Mazzolini, JBS, 80

Ramaprasad \& Mitroff, $A M R, 84$

Schwenk, $A M R, 86$

Sethi, Etemad \& Luther, JBS, 86

Volkema, MS, 83

\section{Dialectical Inquiry/Devil's Advocacy \\ Chanin, \& Shapiro, AMR, 85 \\ Cosier, $A M R, 81 \mathrm{a}$ \\ Cosier, AMR, $8 \mathrm{Ib}$}

\author{
Cosier \& Alpin, SMJ, 80 \\ Mitroff \& Mason, AMR, 81 \\ Schweiger, Sandberg \& Rajan, AMJ, 86 \\ Schwenk, MS, 84b
}

\author{
Other Decision Aids \\ Boland, MS, 84 \\ Dickmeyer, $M S, 83$ \\ Hall \& Menzies, $M S, 83$ \\ Morecroft, SMJ, 84 \\ Mitroff \& Mason, SMJ, 80 \\ Mitroff, Mason \& Barabba, MS, 82 \\ Nutt, $A M R, 82$ \\ Thomas, SMJ, 84 \\ Tuggle and Gerwin, MS, 80 \\ Volkema, SMJ. 86
}

Those offering general prescriptions on decision making include several authors (Bartunek, Gordon \& Weathersby, 1983; Volkema, 1983) who explored the positive benefits of methods that expand the decision makers' understanding of a problem, and several authors (Barnes, 1984; Lenz \& Lyles, 1986; Mazzolini, 1980; Schwenk, 1986) who explored psychological and organizational processes which may limit understanding of strategic issues. Taking another tack, Ramaprasad and Mitroff (1984) drew on Piaget and Jung to understand strategic problem solving. 
A particularly interesting set of work on decision aids began with Churchman's (1971) identification of dialectical inquiry (DI) as one promising approach to problem solving. The dialectic notion, which is based on Hegel's discussion of dialectics, was then more fully developed in Mason and Mitroff (1981). A key idea in dialectical inquiry is that decision makers will profit from a structured debate which systematically presents elements of more than one strategic option. The debate is specifically designed to reveal differences in assumptions that underlie the interpretation of data relevant to the choice situation.

Cosier's (1981) and Schwenk's (1984b) articles represent contributions to a quite lengthy discussion about the possible superiority of providing decision makers with a structured debate that focuses on only one plan, along with a full exploration of its potential shortcomings. This approach, known as the devil's advocate (DA) procedure, was found in laboratory experiments to yield better predictions than dialectical inquiry when the decision making situation presented an alternative moderately different from the initial plan.

The choice between DI and DA is not the only alternative for those seeking help with decision making. Schweiger, Sandberg and Ragan (1986) recently reported a lab study in which groups instructed in a consensus approach were found to be more satisfied than groups using either DI or DA approaches. Thomas (1984) suggested that decision theory techniques can also be used to structure debate about strategic alternatives. Morecroft (1984) made a similar argument for the role of a behavioral simulation using system dynamics modelling in which management intuition and model-generated opinion provided the counterpoints for dialectic argument.

The overall strength of work on Decision Aids is that it recognizes the problematic nature of two things that many in the strategy field have assumed away. First, this research has recognized that coming up with new strategic ideas and a framework within which to understand them is not always easy. Second, this work has recognized that even when the individual has the means for generating new ideas, it is rarely easy to reconcile or coordinate these ideas with the opinions of others in the organization.

A second positive aspect of this work is that it comes closer than any other group of articles considered in this review to approaching the ideals of scientific inquiry. Especially the sustained investigation of DI and DA techniques has shown a group of researchers drawing on the work of each other to advance cumulative understanding of an important topic. Even the claim that one set of research was misunderstood by those in the other camp illustrates the essential tension of scientific discovery, as described by Kuhn (1970) and others.

On the other hand, Ackoff (1981) provided an apt critique that especially fits work on decision aids (although it can also be applied to almost all work on strategic processes):

Most corporate planning is like a ritual rain dance: it has no effect on the weather that follows, but it makes those who engage in it feel that they are in control. Most discussions of the role of models in planning are directed at improving the dancing, not the weather (p. 359)

The Decision Aid group also faces the dilemma of whether they are in fact even 
"improving the dancing." In trying to address real limitations of decision makers, those contributing to this stream of work have devised methods that themselves have an important limitation: that is, they may demand more time and staff support than generally available in strategic situations.

Like the work on Decision Aids, the work labeled as the Evolutionary Prescriptions research stream has maintained that the nature of people and organizations does not allow the heroic definition of strategy followed by its systematic implementation. In fact, many early writers in this tradition (notably Braybrooke and Lindblom, 1963; Lindblom, 1959; and Wrapp, 1967) were suspicious of the ability to predetermine strategy at all. Therefore, their prescriptions tended to dwell on the necessity of devising and implanting small, incremental changes and waiting for feedback before making further changes. More recently, Quinn (1980, 1981) suggested that incrementalism has its own logic that well serves the strategy maker.

Recent articles in this relatively new stream of strategic process research include general prescriptions and a number of more specific applications:

\author{
General Prescriptions \\ Aaker \& Mascarenhas, JBS, 84 \\ Bourgeois \& Brodwin, SMJ, 84 \\ Bougeois, AMJ, 85 \\ Chakravarthy, $A M R, 82$ \\ Fiol \& Lyles, AMR, 85 \\ Ginter \& White, AMR, 82 \\ Hrebiniak \& Joyce, ASQ, 85 \\ Quinn, JBS, 81 \\ Ruefli \& Sarrazin, MS, 81 \\ Tichy, JBS, 83
}

\author{
Applications \\ Bourgeois, SMJ, 80a \\ Nutt, $A M J, 86$ \\ Wu, AMR, 81 \\ Specific Environments \\ Bartlett, JBS, 82 \\ Lioukas \& Chambers, $M S, 81$ \\ Ring \& Perry, AMR, 85
}

Two authors (Ruefli \& Sarrazin, 1981; Tichy, 1983) in this area specifically noted that the environments of private as well as public organizations are changing, thus rendering strategic processes more interactive and more difficult to control. Quinn (1981) and Bourgeois and Brodwin (1984) outlined models of strategy development that closely link strategy formulation and implementation in such circumstances. Flexibility (Aaker \& Mascarenhas, 1984), adaptation (Chakravarthy, 1982), and learning (Fiol \& Lyles, 1985; Ginter \& White, 1982) are some of the key words for the appropriate strategic processes.

These works can be commended as the most realistic of all the prescriptive process literature, especially in their recognition that formulation and implementation are intertwined. The work can be criticized, as can all of the prescriptive work reviewed so far, for being relatively insensitive to the content of the strategic decision, and to the historical context of that decision. We believe that strategy formulation and implementation is affected by what is being decided and, further, that previous experience with decision techniques will affect the success of the most recent prescription.

In a second set of four streams of work, each of which has been more interested in description than prescription, a group of researchers has taken on the task of documenting Planning Practices. These studies have surveyed strategy formulation processes and industry planning practices, usually by mailing questionnaires to large samples of firms. Most of the work in this area has been directed 
at determining whether use of planning methods developed within the normative Planning Prescriptions stream leads to enhanced organizational performance:

Planning-Performance

Armstrong, SMJ, 82: SMJ, 86

Bracker \& Pearson. SMJ. 86

Dyson \& Foster, SMJ, 82

Foster, SM.J, 86

King, $S M J, 83$

Kudla, AMJ, 80

Leontiades \& Tezel, SMJ, 80

Lyles \& Lenz, SMJ 82

Miller \& Friesen, SMI, 83

Ramanujam, Venkatraman \& Camillus, $A M J, 86$

Rhyne, SMJ, 86

Robinson \& Pearce, SMJ, 83

Shrader, Taylor \& Dalton, JOM, 84

Planning System Contingencies

Bazzaz \& Grinyer, SMI. 81

Boulton et al., AMJ, 82
Burnett, Yeskey \& Richardon, JBS, 84

Dickie, SMJ, 84

Grinyer, Al-Bazzaz \& Yasai-Ardekani, SMJ, 86

Henry, JBS, 81

Higgins, SMJ, $81 \mathrm{~b}$

Javidan, SMI, 84

Klein \& Linneman, JBS, 84

Lenz \& Engledow, SMJ. 86

Lindsay \& Rue, AMI, 80

Malaska, SMJ. 85

Rhyne, $S M J, 85$

\section{Other}

Bresser \& Bishop, AMR, 83

Fredrickson \& Mitchell, $A M J, 84$

Mintzberg, SMJ. 81

Robinson \& Pearce, AMR, 84

Two studies that addressed the complexity of the planning-performance linkage exemplify the majority of planning practices research. Rhyne (1986) related financial performance to planning characteristics while controlling for industry effects. He discriminated between five types of planning (ranging from shortterm forecasting to strategic planning) and defined financial performance as longterm ( 10 year) return to investors.

Unlike Rhyne, who divided planning systems into types, Ramanujam, Venkatraman and Camillus (1986) characterized planning systems using seven theoretically important dimensions, including five design elements and two organizational context dimensions. Three areas of performance, fulfillment of planning objectives, relative organizational performance, and satisfaction with the planning system, were investigated.

Although both of these articles can be praised for moving the planning practices stream of research away from single year studies employing single measures of planning and performance with no moderating variables, they can be criticized for the characteristics they share with most of the other work addressed to planning-performance questions. Almost all of this research has used questionnaires mailed to one respondent per organization while concentrating on rational aspects of planning. As these authors themselves often acknowledge, it is impossible to assert causation from correlational methodologies. It is just as possible to believe superior performers have the slack resources necessary to undertake elaborate strategic planning systems as it is to believe superior planning leads to superior performance.

Grinyer, Al-Bazzaz and Yasai-Ardekani (1986) exemplify the planning practices substream concerned with planning contingencies. Through correlation and regression analysis of approximately a dozen planning system characteristics and another dozen contextual contingency variables, they found that certain contextual variables, such as the vulnerability of the core technology, were related to certain planning system characteristics, such as the use of more specialist planners to undertake more sophisticated analyses. Their work constitutes a major contribution because it begins to move away from the generalities that have char- 
acterized prescriptive and descriptive work on planning to address some of the critical contingencies that shape planning systems in practice.

Three additional articles worth noting within the Planning Practice stream are Fredrickson and Mitchell (1984), Bresser and Bishop (1983) and Mintzberg (1981). Fredrickson and Mitchell recognized the need to move away from a narrow focus on the formal planning system to an enlarged focus on the strategic decision making process that includes the formal planning system. Bresser and Bishop, in a thoughtful theoretical piece, explored the possibility that formal planning may actually cause increased intraorganizational contradictions, contradictions partially responsible for the introduction of formal planning. Organizations, they suggested, may be trapping themselves in dysfunctional amplifying loops of more formal planning, leading to more contradictions, leading to more formal planning that ultimately may threaten the viability of the organization. Both these articles are interesting because they called for a more integrative approach to researching planning practices. Mintzberg called attention to the field's lack of precision in defining terms and suggested that disagreement concerning what constitutes planning may partially explain conflicting research results.

Another group of strategy researchers have been interested in documenting the relationships between Structures, Systems and Organizational Outcomes. Research in this area often has been directed by a global change model (Bourgeois \& Brodwin, 1984), a paradigm first articulated by Andrews (1972). The research stream has frequently drawn on early work by Chandler (1962) and Rumelt (1974). To date, normative work (cited under the Sequential Implementation stream of work) has far outstripped descriptive studies concerning the relationship between strategy, structure, systems, and organizational performance. Greater attention has been given to the relationship between structure and performance (Burgelman, 1985; Egelhoff, 1982; Grinyer \& Yasai-Ardekani, 1980; Grinyer, Yasai-Ardekani, \& Al-Bazzaz, 1980; Rumelt, 1974) than has been given to the role of formal systems in implementing strategy (Freedman \& Montanari, 1980). How organizations use formal control, incentive, and information systems to implement strategy and how these subsequently effect performance are largely unexplored areas in strategy research:

\section{Structure}

Bart, SMJ, 86

Burgelman, SMJ, 85

Daniels, Pitts \& Tretter, SMJ, 85

Egelhoff, $A S Q .82$

Ettlie, Bridges \& O'Keefe, MS, 84

Grinyer, Yasai-Ardekani \& Al-Bazzaz, AMJ, 80

Grinyer \& Yasai-Ardekani, $A M J, 80$

Grinyer \& Yasai-Ardekani, $A M J, 81$

Hall \& Saias, SMJ, 80
Miller, SMJ, 86

Miller \& Friesen, AMJ, 80b

\author{
Systems \\ Camillus, AMR, 81 \\ Daft \& Macintosh, JOM, 84 \\ Freedman \& Montanari, , 80 \\ Higgins, JBS, 81a \\ Horovitz, JBS, 84 \\ Horovitz \& Thietart, SMJ, 82
}

Organizational theorists also are interested in exploring organizational structures and systems. It is both interesting and puzzling that strategic management and organizational theory researchers study the same phenomenon (and report their results to the same audience) but work independently of each other. Rarely does either group reference the other's work, nor have they employed the same variables or tested each other's theories. Strategy researchers studying structure, for example, focus on macrostructural types or configurations such as functional, 
divisional, geographic, or matrix (Rumelt, 1974); organizational theorists focus on characteristics or dimensions of structure such as span of control and formalization. In building and testing contingency theories of structure, the two fields also diverge. Strategy researchers have concentrated on the primacy of strategy in determining structure, and organizational theorists have focused on the role of technology in determining structure. Although a review of the organizational theory literature on structure and systems is beyond the scope of this review, we believe researchers in both fields would benefit from a more conscious cross-fertilization of efforts.

New work on the role of organizational structures is being directed toward understanding the role of innovative structures in strategy implementation. Burgelman (1985) reported on the results of one interesting study of strategy and organizational structure. In order to study the factors that make new ventures successful, Burgelman adopted a longitudinal-processual approach to data collection, using grounded theory to guide his attention. He interviewed a variety of managers at one large diversified firm with a successful NVD over a 15-month period and had access to long-range plans of six internal corporate ventures. He found that simply creating a NVD entity was insufficient to foster innovation and development of new businesses. The entire organizational context, including reward structures, must be managed differently in a NVD as compared to mature operating divisions.

A seventh stream of research, on Agendas and Attention, has concentrated on cognitive or psychological, bureaucratic, and political impacts on strategic decision making. Early work by March and Simon (1958), Cyert and March (1963), Bower (1970), Carter (1971) and Witte (1972) on organizational-level behavioral decision models and by Kahneman, Slovic and Tversky (1982) and others on individual-level behavioral decision making are among the precursors to this set of strategy research.

Three major substreams of work are subsumed within the Agendas and Attention research stream:

\author{
Agendas \\ Daft \& Weick, AMR, 84 \\ Dutton, Fahey \& Narayanan, SMJ, 83 \\ Fredrickson, $A M J, 85$ \\ Hambrick, SMJ, 82 \\ Huff, SMJ, 82 \\ Kiesler \& Sproull, ASQ, 82 \\ Smircich \& Stubbart, AMR, 85 \\ Sussman, Ricchio \& Belohlov, SMI, 83 \\ Walsh \& Fahey, JOM, 86 \\ Individual Cognitions \& Perceptions \\ Duhaime \& Schwenk, AMR, 85 \\ Hambrick, SMI, 81 \\ Hambrick \& Mason, AMR, 84 \\ Henderson \& Nutt, MS, 81
}

Political \& Bureaucratic Decision
Fahey, $S M J, 81$
Fredrickson, AMR, 86
Narayanan \& Fahey, AMR, 82
Nutt, ASQ, 84b
Lyles, SMJ, 81
Lyles \& Mitroff, ASQ, 80
Pearce \& DeNisi, AMJ, 83
Schwenk, AMR, 85
Shrivastava, JBS, 85
Shrivastava \& Grant, SMJ, 85
Hogarth \& Makridakis, MS, 81
Isenberg, AMJ, 86
Schwenk, SMJ, $84 \mathrm{a}$
Stahl \& Zimmerer, AMJ, 84 \\ Political \& Bureaucratic Decision Processes \\ Fahey, SMJ, 81 \\ Fredrickson, $A M R, 86$ \\ Narayanan \& Fahey, AMR, 82 \\ Lyles, SMJ, 81 \\ Schwenk, AMR, 85 \\ Shrivastava, JBS, 85 \\ Hogarth \& Makridakis, MS, 81 \\ Schwenk, SMJ, 84a \\ Stahl \& Zimmerer, AMJ, 84
}

Some research has primarily focused on the way in which the agenda for decision making is shaped (Dutton, Fahey \& Narayanan, 1983; Huff, 1982). A larger body of work has been directed toward describing political and bureaucratic strategic 
decision making processes in organizations (Fahey, 1981; Narayanan \& Fahey, 1982; Nutt, 1984b; Schwenk, 1985; Shrivastava \& Grant, 1985). A final group of work has concentrated on how individuals make strategic decisions (Schwenk, 1984a; Stahl \& Zimmerer, 1984).

In addition to being concerned with psychological, bureaucratic, and political processes, all three substreams share other characteristics as well. Researchers have tended to analyze a small cross section of specific individual decisions instead of studying decision making systems or patterns of decisions over time (Mintzberg \& Waters, 1985). In addition, researchers tend to trade generalizability of results for a richer understanding of a few, nonrandomly chosen decision situations. Finally, these researchers are primarily concerned with the earliest stages of strategy formulation while ignoring implementation of the decision.

The paper by Dutton et al. (1983) is a good example of emerging work on strategic issue diagnosis, or the process by which "ambiguous data and vaguely felt stimuli ... are translated into focused issues (i.e., attention organizing acts) and the issues explored (i.e., acts of interpretation)"' (pp. 307-8). Huff (1982) suggested some of the ways the experience of other organizations, particularly similar organizations, influences this process of issue identification. Both of these works recognized that strategic decisions are complex, unique, and interdependent. Because strategic issues do not come preformulated, formulation is open to conflicting definition and can have a significant impact on how the issue is resolved.

Nutt (1984b) exemplifies current work on political and bureaucratic strategic decision making processes in organizations. He studied 78 strategic decisions, each in a separate service organization, in order to deduce organizational decision process types. Using an approach he called "process reconstruction," in which each decision process was divided into activities and profiled into decision stages, Nutt classified the decision processes into five general types. A key finding of the study was "nothing remotely resembling the normative methods described in the literature was carried out" by organizations in the study (pp. 446).

Although also primarily interested in behavioral and political conceptions of strategic decision making, Fahey (1981) broadened attention from single decisions to the study of an interrelated set of decisions made over time. He found, as other studies have, that decisions can be divided into phases. However, he also found that different phases were emphasized at different levels in the firms; different aspects of decisions were attended to by different decisional subunits; and political and bureaucratic concerns often overwhelmed rational concerns as information and proposals were communicated between individuals, subunits, and levels in the organization.

A final approach to understanding agendas and attention has focused on cognitive, perceptual, and other psychological impacts on strategic decision making processes. This research, exemplified by Schwenk (1984a), draws on data from cognitive psychology and behavioral decision theory to describe how actual individual strategy decision making processes differ from rational normative ideals. Schwenk noted several sources in the psychology literature that have listed cognitive simplification processes that strategic decision makers may use to deal 
with complexity, ambiguity and uncertainty. Cognitive simplification processes are only one type of psychological process that potentially influences strategic decision making. Work on various types of "mental maps" is also promising (Fahey \& Narayanan, 1986; Huff \& Fletcher, 1984; McCaskey, 1982; Smircich \& Stubbart, 1985; Sussman, Ricchio \& Belohlov, 1983).

Two of the articles in the area we have labeled Contextual Influences drew upon work done in other fields to describe strategy implementation. Gray and Ariss (1985) suggested strategic change can best be described as a political process, and they outline a political life cycle model with specific propositions about changes in political behavior that might be expected at each stage. Sproull and Hofmeister (1986) drew upon recent work in cognitive psychology to analyze an example of implementing an organizational innovation.

The relatively small number of works in the bibliography classified as examining Contextual Influences is somewhat misleading. This is an area that overlaps substantially with organization behavior and organization theory, from whose domain additional references could be collected in each of the subareas identified as areas of current research on strategy processes:

\section{Environment}

Jauch \& Kraft, AMR, 86

Miller \& Friesen, SMJ, 82

\section{Sensemaking}

Feldman \& March, ASQ. 81

Sproull \& Hofmeiser, JOM, 86

\section{Politics}

Gray \& Ariss, AMR, 85

\author{
Leadership \\ Burgelman, $M S, 83 \mathrm{a}$ \\ Guth \& MacMillan, SMJ, 86 \\ Miller \& Toulouse, MS, 86 \\ Organization \\ Barney, AMR, 86 \\ Jaeger \& Baliga, SMJ,
}

Burgelman's (1983a) complex study is an interesting exemplar of this stream of work. He showed the important roles played by top and middle management in fostering corporate innovation. One of his concerns was how organizations find a balance between order and diversity in their strategic activities; a similar concern motivated Miller and Friesen's (1982) study, which found two subsamples of organizations supporting two very different models of product innovation, the first conservative, the second entrepreneurial. On the leadership side, Burgelman's identification of middle management playing a key role in generating and developing innovations is extended by Guth and Macmillan's (1986) study of middle management motivation to implement strategy.

Finally, the Integrative school of research has tried to encompass many of the preoccupations of the previous schools:

Burgelman, AMR, 83b

Hall, $M S, 84$

Jemison \& Sitkin, AMR, 86

Mintzberg \& McHugh, ASQ, 85

Mintzberg \& Waters, AMJ, 82
Mintzberg \& Waters, SMJ, 85

Murray, SMI 84

Pondy \& Huff, JOM, 85

Van de Ven, MS, 86

This research stream traces its origins both to work from Harvard (e.g., Allison, 1970; Bower, 1970) and Carnegie Mellon (e.g., Cyert \& March, 1963). Although the majority of work in this stream has concentrated on psychological, political, and bureaucratic impacts on the strategic management process, a few works have attempted to reconcile two sets of observed phenomenon within the organization: 
(a) the use of formal planning and analytical techniques and (b) the emergence of patterns in streams of actions and decisions that are not always pre-planned. By studying firms in a longitudinal design, researchers have begun to understand how rational planning and incremental political actions combine to influence strategy. Mintzberg and Waters (1982) coined the phrase strategy formation (as opposed to formulation) to describe these processes. It is a process also well described by Quinn (1980). Researchers interested in understanding complex and subtle strategy formation processes tend to use extensive interviewing within a small number of organizations.

Pondy and Huff (1985) exemplify recent work in the Integrative stream. The results reported in this paper are part of a larger study of issue management in three Chicago-area school districts. Data were collected as issues and decisions unfolded, with the researchers visiting each research site once every two weeks during the most intensive year of the four-year study. The study, driven by multiple (and sometimes conflicting) theories drawn from rational, political, and cognitive sources focuses on the way one school district superintendent was successful in introducing computers into his district with a minimum of fanfare, resistance, or implementation difficulties.

\section{Directions for Future Research}

Reflecting back on the full set of process articles published since 1980, a few articles which we have designated exemplars stand out as the kind of work that we believe especially merits emulation. These have been noted within our review of each research stream. However, the exemplary characteristics can be stated more fully as six pieces of advice we would give to those considering new projects in the strategy area:

1. Build on existing theory and research. In a young field the first publications strike out on their own with few apologies. These articles may create the impression that breaking fresh ground with every publication is expected and desirable. In fact, science is at its heart a community of scholars, and progress is a relative measure. The DA/DI debate within the Decision Aids area is a particularly good example of building on existing work. On the other hand, the Agendas and Attention area is populated with a morass of independent articles, and research progress has been correspondingly hampered.

2. Import concepts and research from related areas. While we are trying to establish ourselves as a field of research with its own track record, we should not ignore the much longer traditions in a large number of sibling sciences, beginning with organization theory and organization behavior and expanding to the basic fields of psychology, sociology, and political science and the richness of experience available in areas like international relations and education. More work like that done by Thomas (1984) and Sproull and Hofmeister (1986) is needed, in which the authors show how concepts and practices from an area outside the main current of thought are relevant to its concerns.

3. Consider the organizational and environmental context. A major contribution of strategy content research in recent years has been to underscore the recognized but sometimes neglected importance of economic context in determining 
the success of organizational strategies. Process research must also consider the import of industrial economics for its own agenda. Rhyne's (1986) article does this for planning research. More work that explicitly considers the effect of context on process needs to be undertaken.

4. Reflect the content of the strategic decision being studied. There is a great need for process researchers to consider the content of strategies. The nature of process is sensitive to the subject being considered, the industry within which the decision is being made, and the history and anticipated future of other decisions. Duhaime and Grant's (1984) work on the process of divestment decision making and Jemison and Sitkin's (1986) work on the process of corporate acquisitions both address this concern.

5. Vary research methods. Each piece of research adds to what is already known in an area. Research projects which employ new and innovative methods are likely to add more to the ongoing research stream than ones that replicate well established methods that have been used often within the stream. For instance, in Planning Practices, this advice means researchers might make significant contributions through contextual analysis of planning procedure manuals. On the other hand, those methods are familiar to researchers who have studied political formulation processes within the Agendas and Attention stream. A greater contribution could be made to this stream by careful large scale surveys, unobtrusive measures, and other methods not usually brought to bear within the stream.

6. Aim for non-intuitive, but supportable hypotheses. Value surprising conclusions. Finally, a viable field, in our view, does not just codify current or ideal practice. It does not just seek to establish empirically the details of widely assumed relationships. The exciting field causes its members to sit up and take notice. The best articles surprise, they suggest new relationships that have not been on people's minds, they upset conventional wisdom. Several articles in our review had these desirable properties, including Bresser and Bishop's (1983) suggestion that formal planning may increase intraorganizational contradictions and Northcraft and Wolf's (1984) suggestion that "throwing good money after bad" may make sense if the individual decision is seen as part of a larger project with its own life cycle.

\section{Implications for Managers}

Three surprises for us in surveying process research may be of particular interest to practicing managers. First, planning research, which we had thought of as being in relative doldrums, is alive and well represented, though our conceptualization of planning is different from the 60 s and early $70 \mathrm{~s}$. Today planning is more implementation-minded and offers more advice on aiding decisions rather than specifying the subject and timing of decisions. Researchers are now being more explicit about what it means to say that "the process of planning is more valuable than the plan itself.,"

Second, we were surprised at the number of articles in the stream we labeled "'agendas and attention," an area that we had viewed as still in the early stages of exploration, but which in fact has attracted a large number of researchers. Given that it is always possible to think of more things than it is possible to do, man- 
agers might be particularly interested in this work, which has focused on why and how managers attend to some strategic issues rather than others.

A third observation of interest is the field's continuing practice of prescribing before describing, of giving normative advice before empirical evidence supports it. This is a problematic practice for an academic field, and yet there is no easy solution for either managers or researchers because the bulk of strategy research does not lend itself to controlled experimentation. Since strategic decisions often threaten the very survival of the firm, managers are understandingly hesitant to sponsor experimentation for the sake of research (as they have for organizational behavior at lower levels in the organization). For managers, relative paucity of empirical evidence means a skeptical eye should still be used in examining most strategic process advice.

\section{Conclusion}

The budding journalist is admonished to cover "who, what, why, when, where and how" in writing the news. Process research can be defined as obsessed with how strategy is formulated and implemented", whereas "what is being decided" has been claimed as the province of content oriented research. Questions of " who is involved in strategy" and "why strategy arises" have been addressed by both groups, but in different ways. The business unit and the corporation have been the focus of content research, whereas process research has tended to be obsessed by the individual and the group. "Why" has been seen primarily as a question of economic performance by content researchers, and process researchers have looked either to logical or behavioral rationales for action. Context and timing, the where and when questions, on the other hand, have tended to be equally neglected by both groups, although some attention is beginning to be given to these questions as well.

The summary point of this review is that the story of strategic management cannot be properly written until all of these issues are included in research design. It is our firm belief that the most significant contribution to research progress in the field will in fact be made by those who cross the boundaries that have been carefully built up over the last several decades.

We believe the field will be best served by cycling back and forth between qualitative and quantitative methods, between comprehensive and focused studies, and between rational and political assumptions. The strategy field, up until ten years ago, was dominated by qualitative, comprehensive case studies. Narrowly focused, large sample size, quantitative studies were a welcome balance to these studies. But there is danger in believing that statistically rigorous, narrowly focused studies are superior to the rich, complicated understanding that results from careful study of a few organizations. Just as broadly focused studies are often open to conflicting interpretations, the tight boundaries that must be drawn around research questions in order to study statistically the relationships between a few variables are artificial ones that may lead researchers to misleading conclusions. More broadly, we hope that it will be harder and harder to survey the field 
in terms of the divisions outlined in Figure 1. In fact, we hope that reviews such as this one will, in the future, be forced by the nature of the work being done in the field to consider both process and content in discussing strategy research.

\section{References}

Aaker, D.A., \& Mascarenhas, B. (1984). The need for strategic flexibility. Journal of Business Strategy, 5(2), 74-82.

Ackoff, R.L. (1970). A concept of corporate planning. New York: Wiley.

Ackoff, R.L. (1981). On the use of models in corporate planning. Strategic Management Journal, 2, 353-359.

Allison, G.T. (1970), Essence of decision. Boston: Little, Brown and Co.

Andrews, K.R. (1971). The concept of corporate strategy. Homewood, IL: Irwin.

Ansoff, H.I. (1965). Corporate Strategy. New York: McGraw-Hill.

Ansoff, H.I. (1980). Strategic issue management. Strategic Management Journal, I, 131-148.

Ansoff, H.I. (1986). Competitive strategy analysis on the personal computer. The Journal of Business Strategy, 6(3), 28-36.

Armstrong, J.S. (1982). The value of formal planning for strategic decisions: Review of empirical research. Strategic Management Journal, 3, 197-211.

Armstrong, J.S. (1986). The value of formal planning for strategic decisions: Reply. Strategic Management Journal, 7, 183-185.

Barnes, J.H. (1984). Cognitive biases and their impact on strategic planning. Strategic Management Journal, 5, 129-137.

Barney, J.B. (1986a). Organizational culture: Can it be a source of sustained competitive advantage? Academy of Management Review, 11, 656-665.

Barney, J. B. (1986b). Strategic factor markets: Expectations, luck, and business strategy. Management Science, 10, 1231-1241.

Bart, C.K. (1986). Product strategy and formal structure. Strategic Management Journal, 7, 293312.

Bartlett, C.A. (1982). How multinational organizations evolve. Journal of Business Strategy, 3(1), 20-32.

Bartunek, J.M., Gordon, J.R., \& Weathersby, R.P. (1983). Developing "complicated" understanding in administrators. Academy of Management Review, 8, 273-284.

Bazzaz, S.J., \& Grinyer, P.H. (1981). Corporate Planning in the U.K.: The state of the art in the 70s. Strategic Management Journal, 2, 155-168.

Blyth, M.L., Friskey, E.A., \& Rappaport, A. (1986). Implementing the shareholder value approach. Journal of Business Strategy, 6(3), 48-58.

Boland, R.J. (1984). Sense-making of accounting data as a technique of organizational diagnosis. Management Science, 30, 868-882.

Boulton, W.R., Lindsay, W.M., Franklin, S.G., \& Rue, L.W. (1982). Strategic planning: Determining the impact of environmental characteristics and uncertainty. Academy of Management Journal, 25, 500-509.

Bourgeois, L.J. (1980a). Performance and consensus. Strategic Management Journal, 1, 227-248.

Bourgeois, L.J. (1980b). Strategy and environment: A conceptual integration. Academy of Management Review, 5, 25-39.

Bourgeois, L.J. (1985). Strategic goals, perceived uncertainty, and economic performance in volatile environments. Academy of Management Journal, 28, 548-573.

Bourgeois, L.J., \& Brodwin, D.R. (1984). Strategic implementation: Five approaches to an elusive phenomenon. Strategic Management Journal, 5, 241-264.

Bower, J.L. (1970). Managing the resource allocation process. Homewood, IL: Irwin.

Bower, J.L. (1982). Solving the problems of business planning. Journal of Business Strategy, 2(3), $32-44$.

Bracker, J.S., \& Pearson, J.N. (1986). Planning and financial performance of small, mature firms. Strategic Management Journal, 7, 503-522.

Braybrooke, D., \& Lindblom, C.E. (1963). A strategy of decision. New York: The Free Press. 
Bresser, R.K., \& Bishop, R.C. (1983). Dysfunctional effects of formal planning: Two theoretical explanations. Academy of Management Review, 8, 588-599.

Bryson, J.M. (1981). A perspective on planning and crises in the public sector. Strategic Management Journal, 2, 181-196.

Burgelman, R.A. (1983a). Corporate entrepreneurship and strategic management: Insights from a process study. Management Science, 29, 1349-1364.

Burgelman, R.A. (1983b). A model of the interaction of strategic behavior, corporate context, and the concept of strategy. Academy of Management Review, 8, 61-70.

Burgelman, R.A. (1983c). A process model of internal corporate venturing in the diversified major firm. Administrative Science Quarterly, 28, 223-244.

Burgelman, R.A. (1985). Managing the new venture division: Research findings and implications for strategic management. Strategic Management Journal, 6, 39-54.

Burnett, C.D., Yeskey, D.P., \& Richardson, D. (1984). New roles for corporate planners in the 1980s. Journal of Business Strategy, 4(4), 64-68.

Camillus, J.C. (1981). Corporate strategy and executive action: Transition stages and linkage dimensions. Academy of Management Review, 6, 253-259.

Camillus, J.C. (1982). Reconciling logical incrementalism and synoptic formalism-an integrated approach to designing strategic planning processes. Strategic Management Journal, 3, $277-$ 283.

Camillus, J.D., \& Grant, J.H. (1980). Operational Planning: The integration of programming and budgeting. Academy of Management Review, 5, 369-379.

Carter, E.E. (1971). The behavioral theory of the firm and top-level corporate decision. Administrative Science Quarterly, 16, 413-429.

Chakravarthy, B.S. (1982). Adaptation: A promising metaphor for strategic management. Academy of Management Review, 7, 35-44.

Chakravarthy, B.S. (1984). Strategic self-renewal: A planning framework for today. Academy of Management Review, 536-547.

Chandler, A.D. (1962). Strategy and structure: Chapters in the history of the American industrial enterprise. Cambridge, MA: MIT Press.

Chanin, M.N., \& Shapiro, H.J. (1985). Dialectical inquiry in strategic planning: Extending the boundaries. Academy of Management Review, 10, 663-675.

Charan, R. (1982). How to strengthen your strategy review process. Journal of Business Strategy, $2(3), 50-60$.

Churchman, C.W. (1971). The design of inquiring systems. New York, NY: Basic Books.

Cosier, R.A. (1981a). Dialectical inquiry in strategy planning: A case of premature acceptance? Academy of Management Review, 6, 643-648.

Cosier, R.A. (1981b). Further thoughts on dialectical inquiry: A rejoinder to Mitroff and Mason. Academy of Management Review, 6, 653-654.

Cosier, R.A., \& Aplin, J.C. (1980). A critical view of dialectical inquiry as a tool in strategic planning. Strategic Management Journal, I, 343-356.

Cyert, R.M., \& March, J.C. (1963). A behavioral theory of the firm. Englewood Cliffs, NJ: Prentice-Hall.

Daft, R.L., \& Macintosh, N.B. (1984). The nature and use of formal control systems for management control and strategy implementation. Journal of Management, 10, 43-66.

Daft, R.L., \& Weick, K.E. (1984). Toward a model of organizations as interpretative systems. Academy of Management Review, 9, 284-295.

Daniels, J.D., Pitts, R.A., \& Tretter, M.A. (1985). Organizing for duel strategies of product diversity and international expansion. Strategic Management Journal, 6, 223-237.

Day, G. (1983). Gaining insights through strategy analysis. Journal of Business Strategy, 4(1), 5158.

Day, G.S. (1986). Tough questions for developing strategies. Journal of Business Strategy, 6(3), 60-68.

Desta, A. (1985). Assessing political risk in less developed countries. Journal of Business Strategy, $5(4), 40-53$.

Dickmeyer, N. (1983). Measuring the effects of a university planning aid. Management Science, $29,673-685$. 
Diffenbach, J. (1982). Influence diagrams for complex strategic issues. Strategic Management Journal, 3, 133-146.

Duhaime, I.M., \& Grant, J.H. (1984). Factors influencing divestment decision-making: Evidence from a field study. Strategic Management Journal, 5, 301-318.

Duhaime, I.M., \& Schwenk, C.R. (1985). Conjectures on cognitive simplification in acquisition and divestment decision making. Academy of Management Review, 10, 287-295.

Dutta, B.K., \& King, W.R. (1980). Metagame analysis of competitive strategy. Strategic Management Journal, $1,357-370$.

Dutton, J.E., Fahey, L., \& Narayanan, V.K. (1983). Toward understanding strategic issue diagnosis. Strategic Management Journal, 4, 307-324.

Dyson, R.G., \& Foster, J.J. (1982). The relationship of participation and effectiveness in strategic planning. Strategic Management Journal, 3, 77-88.

Edmunds, S.W. (1982). The role of futures studies in business strategic planning. Journal of Business Strategy, 3, 40-46.

Egelhoff, W.G. (1982). Strategy and structure in multinational corporations, Administrative Science Quarterly, 27, 435-458.

Eisenhardt, K.M. (1985). Control: Organizational and economic approaches. Management Science, 31, 134-149.

Ettlie, J.E., Bridges, W.P., \& O'Keefe, R.D. (1984). Organization strategy and structural differences for radical versus incremental innovation. Management Science, 30, 682-695.

Fahey, L. (1981). On the strategic management decision process. Strategic Management Journal, 2, 43-60.

Fahey, L., \& Christensen, H.K. (1986). Evaluating the research of strategy content. Journal of Management, 12, 167-183.

Fahey, L., \& Narayanan, V.K. (1986). Organizational beliefs and strategic adaptation. In J.A. Pearce \& R.B. Robinson (Eds.), Best Papers Proceedings: Academy of Management (pp. 7 11). Columbia, S.C.: Academy of Management.

Feldman, M.S., \& March, J.G. (1981). Information in organizations as signal and symbol. Administrative Science Quarterly, 26, 171-186.

Fiol, C.M., \& Lyles, M.A. (1985), Organizational learning. Academy of Management Review, 10 , $803-813$

Fombrun, C., \& Astley, W.G. (1983). Beyond corporate strategy. Journal of Business Strategy, $3(4), 47-54$.

Foster, M.J. (1986). The value of formal planning for strategic decisions; a comment. Strategic Management Journal, 7, 179-182.

Fredrickson, J.W. (1983). Strategic process research: Questions and recommendations. Academy of Management Review, 8, 565-575.

Fredrickson, J.W. (1984). The comprehensiveness of strategic decision processes: Extensions, observations, future directions. Academy of Management Journal, 27, 445-466.

Fredrickson, J.W. (1985). Effects of decision motive and organizational performance level on strategic decision processes. Academy of Management Journal, 28, 821-843.

Fredrickson, J.W. (1986). The strategic decision process and organizational structure. Academy of Management Review, 11, 280-297.

Fredrickson, J.W., \& Mitchell, T.R. (1984). Strategic decision processes: Comprehensiveness and performance in an industry with an unstable environment. Academy of Management Journal, 27, 399-423.

Freedman, S.M., \& Montanari, J.R. (1980). An integrative model of managerial reward allocation. Academy of Management Review, 5, 381-390.

Galbraith, J.R., \& Kazanjian, R.K. (1986). Strategy implementation: Structure, systems and process. St. Paul, MN: West.

Galbraith, J.R., \& Nathanson, D.A. (1978). Strategy implementation: The role of structure and process. St. Paul, MN: West.

Gharajedaghi, J., \& Ackoff, R.L. (1984). Mechanisms, organisms and social systems. Strategic Management Journal, 5, 289-300.

Ginsberg, A. (1984). Operationalizing organizational strategy: Toward an integrative framework. Academy of Management Review, 9, 548-557. 
Ginsberg, A., \& Venkatraman, N. (1985). Contingency perspectives of organizational strategy: A critical review of the empirical research. Academy of Management Review, 10, 421-434.

Ginter, P.M., \& White, D.D. (1982). A social learning approach to strategic management: Toward a theoretical foundation. Academy of Management Review, 7, 253-261.

Gray, B., \& Ariss, S.S. (1985). Politics and strategic change across organizational life cycles. Academy of Management Review, 10, 707-723.

Grinyer, P., Al-Bazzaz, S., \& Yasai-Ardekani, M. (1986). Towards a contingency theory of corporate planning: Findings in 48 U.K. companies. Strategic Management Journal, 7, 3-28.

Grinyer, P.H., \& Yasai-Ardekani, M. (1980). Dimensions of organizational structure: A critical replication. Academy of Management Journal, 23, 405-421.

Grinyer, P.H., \& Yasai-Ardekani, M. (1981). Strategy, structure, size and bureaucracy. Academy of Management Journal, 24, 471-486.

Grinyer, P.H., Yasai-Ardekani, M., \& Al-Bazzaz, S. (1980). Strategy, structure, the environment and financial performance in 48 United Kingdom companies. Academy of Management Journal, $23,193-220$.

Gupta, A.K. (1984). Contingency linkages between strategy and general manager characteristics: A conceptual examination. Academy of Management Review, 9, 399-412.

Gupta, A.K., \& Govindarajan, V. (1984). Business unit strategy, managerial characteristics and business unit effectiveness at strategy implementation. Academy of Management Journal, 27, $25-41$.

Guth, W.D., \& MacMillan, I.C. (1986). Strategy implementation versus middle management selfinterest. Strategic Management Journal, 7, 313-327.

Hall, D.J., \& Saias, M.A. (1980) Strategy follows structure! Strategic Management Journal, I, 149-163.

Hall, R.I. (1984). The natural logic of management policy making: Its implications for the survival of an organization. Management Science, 30, 905-927.

Hall, R.I., \& Menzies, W.B. (1983). A corporate system model of a sports club: Using simulation as an aid to policy making in a crisis. Management Science, 29, 52-64.

Hambrick, D.C. (1981). Strategic awareness within top management teams. Strategic Management Journal, 2, 263-279.

Hambrick, D.C. (1982). Environmental scanning and organizational strategy. Strategic Management Journal, 3, 159-174.

Hambrick, D.C. \& Mason, P.A. (1984). Upper echelons: The organization as a reflection of its top managers. Academy of Management Review, 9, 193-206.

Hatten, M.L. (1982). Strategic management in not-for-profit organizations. Strategic Management Journal, 3, 89-104.

Hax, A.C., \& Majluf, N.S. (1983). Organization design: A case study on matching strategy and structure. Journal of Business Strategy, 3(3), 72-86.

Henderson, J.C., \& Nutt, P.C. (1980). The influence of decision style on decision making behavior. Management Science, 26, 371-386.

Henry, H.W. (1981). Then and now: A look at strategic planning systems. Journal of Business Strategy, I(3), 64-69.

Higgins, R.B. (1981a). How well are we rewarding our managers for strategic planning. Journal of Business Strategy, I(3), 77-83.

Higgins, R.B. (1981b). Long range planning in the mature corporation. Strategic Management Journal, 2, 235-250.

Hofer, C.W., \& Haller, T.P. (1980). Globescan: A way to better international risk assessment. Journal of Business Strategy, l(2), 41-55.

Hoffman, R.G. (1985). Economic scenarios for project evaluation. Journal of Business Strategy, 5 , 66-74.

Hogarth, R.M., \& Makridakis, S. (1981). Forecasting and planning: An evaluation. Management Science, 27, 115-138.

Horovitz, J. (1984). New perspectives on strategic management. Journal of Business Strategy, 4(4), 19-33.

Horovitz, J.H., \& Thietart, R.A. (1982). Strategy, management design and firm performance. Strategic Management Journal, 3, 67-76. 
Hosmer, L.T. (1982). The importance of strategic leadership. Journal of Business Strategy, 3(2), 47-57.

Hrebiniak, L.G., \& Joyce, W.F. (1984). Implementing strategy. New York: MacMillan.

Hrebiniak, L.G., \& Joyce, W.F. (1985). Organizational adaptation: Strategic choice and environmental determinism. Administrative Science Quarterly, 30, 336-349.

Huff, A.S. (1982). Industry sense-making. Strategic Management Journal, 3, 119-131.

Huff, A.S. (1985). Managerial implications of the emerging paradigm. In Y.S. Lincoln (Ed.), Organizational theory and inquiry. (pp. 161-183). Beverly Hills, CA: Sage.

Hunsicker, J.Q. (1980). Can top managers be strategists? Strategic Management Journal, 1, 77-83.

Isenberg. D.J. (1986). Thinking and managing: A verbal protocol analysis of managerial problem solving. Academy of Management Journal, 29, 775-788.

Jaeger, A.M., \& Baliga, B.R. (1985). Control systems and strategic adaptations: Lessons from the Japanese experience. Strategic Management Journal, 6, 115-134.

Jauch, L.R., \& Kraft, K.L. (1986). Strategic management of uncertainty. Academy of Management Review, 11, 777-790.

Jauch, L.R., Martin, T.N., \& Osborn, R.N. (1981). Top management under fire. Journal of Business Strategy, I(4), 33-41.

Javidan, M. (1984). The impact of environmental uncertainty on long-range planning practices in the U.S. savings and loan industry. Strategic Management Journal, 5, 381-392.

Jemison, D. B. (1981). The contributions of administrative behavior to strategic management. Academy of Management Review, 6, 601-608.

Jemison, D.B., \& Sitkin, S.S. (1986). Corporate acquisitions: A process perspective. Acaciemy of Management Review, 11, 145-163.

Kahneman, D., Slovic, P., \& Tuersky, A., (Eds.). (1982). Judgment under uncertainty: Heuristics and biases. New York: Cambridge University Press.

Kerr, J. (1985). Diversification strategies and managerial rewards: An empirical study. Academy of Management Journal, 28, 155-179.

Kiesler, S., \& Sproull, L. (1982). Managerial response to changing environments: Perspectives on problem sensing from social cognition. Administrative Science Quarterly, 27, 548-570.

King, W.R. (1981). The importance of strategic issues. Journal of Business Strategy, 1(3), 74-76.

King, W.R. (1983). Evaluating strategic planning systems. Strategic Management Journal, 4, $263-$ 278.

King, W.R., \& Rodriguez, J.I. (1981). Participative design of strategic decision support systems: An empirical assessment. Management Science, 27, 717-726.

Klein, H., \& Newman, W. (1980). How to use Spire: A systematic procedure for identifying relevant environments for strategic planning. Journal of Business Strategy, I(1), 32-45.

Klein, H.E., \& Linneman, R.E. (1984). Environmental assessment: An international study of corporate practice. Journal of Business Strategy, 5(1), 66-75.

Kudla, R.J. (1980). The effects of strategic planning on common stock returns. Academy of Management Journal, 23, 5-20.

Kuhn, T. (1970). Structure of scientific revolution (2nd ed.). Chicago: Chicago University Press.

Kunreuther, H., Linnerooth, J., \& Vaupel, J.W. (1984). A decision-process perspective on risk and policy analysis. Management Science, 30, 475-485.

Lauenstein, M.C. (1986). The failure of strategic planning. Journal of Business Strategy, 6(4), 7566.

Lenz, R.T., \& Engledow, J.L. (1986). Environmental analysis units and strategic decision-making: A field study of selected "leading edge" corporations. Strategic Management Journal, 7, 6989.

Lenz, R.T., \& Lyles, M.A. (1986). Managing human problems in strategic planning systems. Journal of Business Strategy 6(4), 57-66.

Leontiades, M. (1982). Choosing the right manager to fit the strategy. Journal of Business Strategy, $3(2), 58-69$.

Leontiades, M. (1983), A diagnostic framework for planning. Strategic Management Journal, 4 , $11-26$.

Leontiades, M., \& Tezel, A. (1980). Planning perceptions and planning results. Strategic Management Journal, I, 65-75. 
Lindblom, C.E. (1959). The science of "muddling through." Public Administration Review, 19, 79-88.

Lindsay, W.M., \& Rue, L.W. (1980). Impact of the organization environment on the long-range planning process: A contingency view. Academy of Management Journal, 23, 385-404.

Lioukas, S.K., \& Chambers, D.J. (1981). The boundary between planning and incremental budgeting: empirical examination in a publicly-owned corporation. Management Science, 27, 14211434.

Lorange, P., \& Murphy, D. (1984). Considerations in implementing strategic control. Journal of Business Strategy, 4(4), 27-35.

Lorange, P., Scott Morton, M.S., \& Ghoshal, S. (1986). Strategic control systems. St. Paul, MN: West.

Lyles, M.A. (1981). Formulating strategic problems: Empirical analysis and model development. Strategic Management Journal, 2, 61-75.

Lyles, M.A., \& Lenz, R.T. (1982). Managing the planning process: A field study of the human side of planning. Strategic Management Journal, 3, 105-118.

Lyles, M.A., \& Mitroff, (1980). Organizational problem formulation: An empirical study. Administrative Science Quarterly, 25, 109-119.

Mahon, J.F., \& Murray, E.A. (1981). Strategic planning for regulated companies. Strategic Management Journal, 2, 251-262.

Malaska, P. (1985). Multiple scenario approach and strategic behavior in European companies. Strategic Management Journal, 6, 339-355.

March, J.G., \& Simon, H.A. (1958). Organizations. New York: Wiley.

Mason, R.O., \& Mitroff, I.I. (1981). Challenging strategic planning assumptions. New York: Wiley.

Mazzolini, R. (1980). Real-world decision making: The limits of top management power. Journal of Business Strategy, I(2), 3-8.

McCaskey, M.B. (1982). The executive challenge: Managing change and ambiguity. Boston: Pitman.

McGinnis, M.A., \& Ackelsberg, M.R. (1983). Effective innovation management: Missing link in strategic planning? Journal of Business Strategy, 4(1), 59-66.

McInnes, J.M., \& Carleton, W.J. (1982). Theory, models and implementation in financial management. Management Science, 28, 957-978.

Melcher, A.J., \& Melcher, B.H. (1980). Toward a systems theory of policy analysis: Static versus dynamic analysis. Academy of Management Review, 5, 235-247.

Miesing, P., \& Wolfe, J. (1985). The art and science of planning at the business unit level. Management Science, 31, 773-781.

Miller, D. (1986). Configurations of strategy and structure: Towards a synthesis. Strategic Management Journal, 7, 233-249.

Miller, D., \& Friesen, P. (1980a). Archetypes of organizational transition. Administrative Science Quarterly, 25, 268-299.

Miller, D., \& Friesen, P.H. (1980b). Momentum and revolution in organizational adaptation. Academy of Management Journal, 23, 591-614.

Miller, D., \& Friesen, P.H. (1982). Innovation in conservative and entrepreneurial firms: Two models of strategic momentum. Strategic Management Journal, 3, 1-25.

Miller, D., \& Friesen, P.H. (1983). Strategy-making and environment: The third link. Strategic Management Journal, 4, 221-235.

Miller, D., \& Toulouse, J.M. (1986). Chief executive personality and corporate strategy and structure in small firms. Management Science, 32, 1389-1409.

Mintzberg, H. (1980). Structure in 5's: A synthesis of the research on organization design. Management Science, 26, 322-341.

Mintzberg, H. (1981). What is planning anyway? Strategic Management Journal, 6, 257-272.

Mintzberg, H. (1985). Strategy formation in an adhocracy. Administrative Science Quarterly, 30 , 160-197.

Mintzberg, H., \& Waters, J.A. (1982). Tracking strategy in an entrepreneurial firm. Academy of Management Journal, 25, 465-499. 
Mintzberg. H., \& Waters, J.A. (1985). Of strategies, deliberate and emergent. Strategic Management Journal, 6, 257-272.

Mintzberg, H., Raisinghani, D., \& Theoret, A. (1976). The structure of unstructured decision processes. Administrative Science Quarterly, 21, 246-276.

Mitchell, F.H., \& Mitchell, C.C. (1980). Development, application, and evaluation of an " actionreaction" planning method. Academy of Management Review, 5, 83-87.

Mitroff, I.I., \& Mason, R.O. (1980). Structuring ill-structured policy issues: Further explorations in a methodology for messy problems. Strategic Management Journal, 1, 331-342.

Mitroff, I.I., \& Mason, R.O. (1981). The metaphysics of policy and planning. A reply to Cosier. Academy of Management Review, 6, 649-651.

Mitroff, I.I., \& Mason, R.O. (1982). Business policy and metaphysics: Some philosophical considerations. Academy of Management Review, 7, 361-371.

Mitroff, I.I., Mason, R.O., \& Barabba, V.P. (1982). Policy as argument-a logic for ill-structured decision problems. Management Science, 28, 1391-1404.

Mokwa, M.P. (1986). The strategic marketing audit: An adoption/utilization perspective. Journal of Business Strategy, 6(4), 88-95.

Molz, R. (1985). The role of the board of directors: Typologies of interaction. Journal of Business Strategy, 5(4), 86-93.

Montanari, J.R., \& Bracker, J.S. (1986). The strategic management process at the public planning level. Strategic Management Journal, 7, 251-265.

Morecroft, J.D.W. (1984). Strategy support models. Strategic Management Journal, 5, 215-230.

Mueller, G., \& Smith, J.B. (1984). Six “commandments"' for successful futures studies for corporate planning. Journal of Business Strategy, 5(2), 88-92.

Murray, J.A. (1984). A concept of entrepreneurial strategy. Strategic Management Journal, 5, 113.

Narayanan, V.K., \& Fahey, L. (1982). The politics of strategy formulation. Academy of Management Review, 7, 25-34.

Naylor, T.H., \& Tapon, R. (1982). The capital asset pricing model: An evaluation of its potential as a strategic planning tool. Management Science, 28, 1166-1173.

Northcraft, G.B., \& Wolf, G. (1984). Dollars, sense, and sunk costs: A life cycle model of research allocation decisions. Academy of Management Review, 9. 225-234.

Nutt, P.C. (1982). Hybrid planning methods. Academy of Management Review, 7, 442-454.

Nutt, P.C. (1983). Implementation approaches for project planning. Academy of Management Review, 8, 600-611.

Nutt, P.C. (1984a). A strategic planning network for non-profit organizations. Strategic Management Journal, 5, 57-75.

Nutt, P.C. (1984b). Types of organizational decision processes. Administrative Science Quarterly, $29,414-450$.

Nutt, P.C. (1986). Tactics of implementation. Academy of Management Journal, 29, 230-261.

Pearce, J.A., \& DeNisi, A.S. (1983). Attribution theory and strategic decision making: An application to coalition formation. Academy of Management Journal, 26, 119-128.

Pondy, L.R., \& Huff, A.S. (1985). Achieving routine in organizational change. Journal of Management, II, 103-116.

Quinn, J.B. (1980). Strategies of change: Logical incrementalism. Homewood, IL: Irwin.

Quinn, J.B. (1981). Formulating strategy one step at a time. Journal of Business Strategy, I(3), 4263.

Ramanujam, V., Venkatraman, N., \& Camillus, J.C. (1986). Multi-objective assessment of effectiveness of strategic planning: A discriminant analysis approach. Academy of Management Journal, 29, 347-372.

Ramaprasad, A., \& Mitroff, I.I. (1984). On formulating strategic problems. Academy of Management Review, 9, 597-605.

Rhyne, L.C. (1985). The relationship of information usage characteristics to planning system sophistication: An empirical examination. Strategic Management Journal, 6, 319-337.

Rhyne, L.C. (1986). The relationship of strategic planning to financial performance. Strategic Management Journal, 7, 423-436. 
Ring, P.S., \& Perry, J.L. (1985). Strategic management in public and private organizations: Implications of distinctive contexts and constraints. Academy of Management Review, 10, 276-286.

Robinson, R.B., Jr., \& Pearce, J.A. (1983). The impact of formalized strategic planning on financial performance in small organizations. Strategic Management Journal, 4, 197-208.

Robinson, R.B., Jr., \& Pearce, J.A. (1984). Research thrusts in small firm strategic planning. Academy of Management Review, 9, 128-137.

Ruefli, T., \& Sarrazin, J. (1981). Strategic control of corporate development under ambiguous circumstances. Management Science, 27, 1158-1170.

Rumelt, R.P. (1974). Strategy, structure and economic performance. Boston: Division of Research, Harvard Business School.

Schendel, D.E., \& Hofer, C.W. (1979). Strategic management: A new view of business policy and planning. Boston: Little, Brown and Co.

Schweiger, D.M., \& Finger, P.A. (1984). The comparative effectiveness of dialectical inquiry and devil's advocacy: The impact of task biases on previous research findings. Strategic Management Journal, 5, 335-350.

Schweiger, D.M., Sandberg, W.R., \& Ragan, J.W. (1986). Group approaches for improving strategic decision making: A comparative analysis of dialectical inquiry, devil's advocacy, and consensus. Academy of Management Journal, 29, 51-71.

Schwenk, C.R. (1984a). Cognitive simplification processes in strategic decision-making. Strategic Management Journal, 5, 111-128.

Schwenk, C.R. (1984b). Effects of planning aids and presentation media on performance and affective responses in strategic decision-making. Management Science, 30, 263-272.

Schwenk, C.R. (1985). The use of participant recollection in the modelling of organization decision processes. Academy of Management Review, 10, 496-503.

Schwenk, C.R. (1986). Information, cognitive biases, and commitment to a course of action. Academy of Management Review, 11, 298-310.

Sethi, S.P., Etemad, H., \& Luther, K.A.N. (1986). New sociopolitical forces: the globalization of conflict. Journal of Business Strategy, 6(4), 24-31.

Shrader, C.B., Taylor, L., \& Dalton, D.R. (1984). Strategic planning and organizational performance: A critical appraisal. Journal of Management, 10, 149-171.

Shrivastava, P. (1985). Integrating strategy formulation with organizational culture. Journal of Business Strategy, 5(3), 103-111.

Shrivastava, P. (1986). Postmerger integration. Journal of Business Strategy, 7(1), 65-76.

Shrivastava, P., \& Grant, J.H. (1985). Empirically derived models of strategic decision-making processes. Strategic Management Journal, 6, 97-113.

Simon, H.A. (1979). Rational decision making in business organizations. American Economics Review, 493-513.

Smircich, L., \& Stubbart, C. (1985). Strategic management in an enacted world. Academy of Management Review, 10, 724-736.

Snyder, N.H. (1982). What is planning anyway? A rejoinder. Strategic Management Journal, 3 , 265-268.

Snyder, C.A., Cox, J.R., \& Jesse, R.R. (1982). A dependent demand approach to service organization planning and control. Academy of Management Review, 7, 455-466.

Sproull, L.S., \& Hofmeister, K.R. (1986). Thinking about implementation. Journal of Management, 12, 43-60.

Stahl, M.J., \& Zimmerer, T.W. (1984). Modeling strategic acquisition policies: A simulation of executives' acquisition decisions. Academy of Management Journal, 27, 369-383.

Steiner, G.A. (1969). Top management planning. New York: MacMillan.

Steiner, G.A. (1979). Strategic planning: What every manager must know. New York: The Free Press.

Stengrevics, J.M. (1984). Making cluster strategies work. Journal of Business Strategy, 5(2), $106-$ 111.

Stonich, P.J. (1980). How to use strategic funds programming. Journal of Business Strategy, I(2), 35-40.

Stonich, P.J. (1981). Using reward in implementing strategy. Strategy Management Journal, 2 , 345-352. 
Sussman, L., Ricchio, P., \& Belohlav, J. (1983). Corporate speeches as a source of corporate values: An analysis across years, themes and industries. Strategic Management Journal, 4, 187 196.

Szilagyi, A.D., \& Schweiger, D.M. (1984). Matching managers to strategies: A review and suggested framework. Academy of Management Reyiew, 9, 626-637.

Thomas, H. (1984). Strategic decision analysis: Applied decision analysis and its role in the strategic management process. Strategic Management Journal, 5, 139-156.

Tichy, N. (1983). The essentials of strategic change management. Journal of Business Strategy, 3(4), 55-67.

Tuggle, F.D., \& Gerwin, D. (1980). An information processing model of organization perception, strategy and choice. Management Science, 26, 575-592.

Van Cauwenbergh, A., \& Cool, K. (1982). Strategic management in a new framework. Strategic Management Journal, 3, 245-264.

Van de Ven, A.H. (1986). Central problems in the management of innovation. Management Science, 32, 590-607.

Volkema, R.J. (1983). Problem formulation in planning and design. Management Science, 29. 639-652.

Volkema, R.J. (1986). Problem formulation as a purposive activity. Strategic Management Journal, 7, 267-279.

Walsh, J.P., \& Fahey, L. (1986). The role of negotiated belief structures in strategy making. Journal of Management, 12, 325-338.

Wissema, J.G., Brand, A.F., \& Van der Pol, H.W. (1981). The incorporation of management development in strategic management. Strategic Management Journal, 2, 361-377.

Witte, E. (1972). Field research on complex decision making processes- the phase theorem. International Studies of Management and Organization, 2, 156-182.

Woo, C.Y. (1984). An empirical test of value-based planning models and implications. Management Science, 30, 1031-1050.

Wrapp, H.E. (1967, September-October). Good managers don't make policy decisions. Harvard Business Review, pp. 91-99.

Wu, F.H. (1981). Incrementalism in financial strategic planning. Academy of Management Review, 6. 133-143.

Yip, G.S. (1985). Who needs strategic planning? Journal of Business Strategy, 6(2), 30-42. 
Copyright of Journal of Management is the property of Sage Publications, Ltd. and its content may not be copied or emailed to multiple sites or posted to a listserv without the copyright holder's express written permission. However, users may print, download, or email articles for individual use. 